\title{
"Citizens without Borders"?: Discussions of Transnationalism and Forced Migrants at the Ninth Conference of the International Association for the Study of Forced Migration, São Paulo, Brazil, January 2005
}

\author{
Michael Collyer
}

\begin{abstract}
The significance of transnational perspectives at the ninth conference of the International Association for the Study of Forced Migration (IASFM) marks a key change in the development of work on both forced migration and migrant transnationalism. A transnational perspective highlights significant policy interventions that can be made in the search for durable solutions to refugee displacement; most significantly, recognizing that a refugee's community may be spread on a global scale, yet is nonetheless significant in supporting their own efforts to overcome the difficulties of their situation. It is equally important, however, to recognize that transnational activites do not always support pluralistic solutions to conflict. The transnational engagements of forced migrants also challenge a number of assumptions of existing transnational perspectives by directing attention to forms of exchanges and communication that do not necessariy involve the movements of people. Interest in transnational activities is currently concentrated amongst researchers working in the wealthier countries of the global North. Further work may determine if alternative perspectives are more appropriate for research based in the South.
\end{abstract}

\section{Résumé}

La signification des perspectives transnationales au neuvième congrès de l'Association internationale des études sur la migration forcée (IASFM) marque un jalon dans l'élaboration du travail sur la migration forcée et le transnationalisme migrant. Une perspective transnationale met en relief les interventions significatives en matière de politique qui peuvent être entreprises en vue de trouver des solutions durables au déplacement des réfugiés. Elle permet, en particulier, de reconnaître qu'une communauté de réfugiés pouvant être disséminée à l'échelle mondiale joue tout de même un rôle capital pour aider ses membres à surmonter les difficultés auxquelles ils font face. Toutefois, il faut reconnaître que les activités transnationales ne favorisent pas toujours des solutions plurielles aux conflits. Les engagements transnationaux des migrants forcés remettent aussi en question un grand nombre de présupposés sur les perspectives transnationales courantes en insistant sur des formes d'échanges et de communication qui n'impliquent pas nécessairement des déplacements de personnes. Les activités transnationales intéressent actuellement les chercheurs auvrant dans les pays les mieux nantis du nord planétaire. Des travaux ultérieurs permettront de déterminer si d'autres perspectives sont plus appropriées à la recherche effectuée dans le sud. 
$\mathrm{M}$ igrant transnationalism has typically been associated with voluntary migrants. Its connection with mobility, and particularly regular returns to the point of origin, initially precluded refugees and other groups of forced migrants. More recently, however, it has also raised interest in the context of refugee movement. ${ }^{1}$ Of the three traditionally conceived durable solutions for refugees, two of them, resettlement and return, do require international mobility. Work on refugee transnationalism has also been encouraged, in part, by a change of emphasis to the non-mobile aspects of transnational linkages, that are particularly relevant in the case of local integration and resettlement but also in the large number of unresolved refugee situations. It is therefore not surprising that transnationalism formed a significant theme of the ninth biennial conference of the International Association for the Study of Forced Migration (IASFM), that was held in São Paulo from January 9 to 13, 2005, and entitled The Search for Solutions: Achievements and Challenges.

There is still no broadly accepted definition of transnationalism; indeed the concept itself continues to raise controversy, but, after more than a decade of scholarship in the field, the boundaries of what is meant by migrant transnationalism are becoming more clearly defined. ${ }^{2}$ There is still considerable pressure for a restrictive definition of transnational practices, on the basis that only then will the concept be clearly differentiated from what migrants have always done anyway. ${ }^{3}$ However, in the context of the IASFM conference much broader understandings, encompassing mobility of people, but also other forms of links and exchanges, were far more common.

Such broad understandings of the concept are clearly appropriate to investigate the nature of the contacts that less mobile migrants maintain with their point of origin. Papers at the conference continually emphasized that poor, disempowered, and politically excluded groups make up the majority of forced migrants, at a global scale. Although forced migrants are unlikely to find themselves amongst the transnational elite that commentators such as Portes have in mind when they speak of "simultaneous presence" in more than one country, the nature and extent of their transnational ties remains an important factor in determining the possibilities open to them. ${ }^{4}$ More importantly, in relation to the theme of the conference, transnational relationships may well be a determining factor in the search for longerterm solutions to situations of forced migration.

Four panels of the São Paulo conference were devoted entirely to transnational themes and many of the remaining fifty-five panels touched on migrant transnationalism in one sense or another. The conference was held under Chatham House rules, meaning that nothing that was said is attributable to individuals, but this paper sets out a summary of the main themes of discussion. Since the conference focused on solutions to refugee displacement the following three sections consider contributions relating transnational interactions to return, resettlement, and local integration with a fourth section on transnational concerns in protracted refugee situations and a final section considering aspects of transnationalism relating to other aspects of forced migration.

\section{Transnationalism and Local Integration}

The separate classification of the various forms of solutions into distinct categories is clearly more of a heuristic device than a reflection of the experiences of refugees. This point was emphasized most in papers investigating processes of integration of refugees, since integration may occur de facto, while progress towards an alternative solution is awaited. Integration remains one of the key contested concepts in work with refugees, and migration studies more generally, perhaps most recently expressed in debates opposing transnationalism and assimilation. ${ }^{5}$ Papers at the conference spent little time on precise definitions but generally used "integration" to refer to a process of gradual familiarization with an initially unfamiliar society, usually involving growing economic and eventually political involvement in that society but usually not acculturation to its dominant social and cultural norms. "Local integration" traditionally refers to integration in the country of first asylum, which was the subject of several panels, but a range of papers also explored processes of integration in the context of resettlement or final country of asylum in Western Europe or North America which was not always the country of first asylum.

The language of transnationalism was largely absent from discussions of local integration in the country of first asylum where that country was located in the South. This is a reflection of the geographical bias of the literature on transnationalism which concentrates on the receiving context of North America, and to a lesser extent Western Europe, to the virtual exclusion of communities in the rest of the world. One panel, which presented three papers exploring notions of "refugees as solvers," did emphasize the role of diaspora networks, not only in providing funds for displaced communities but also in influencing the politics of aid and humanitarian assistance programs. The significance of recognizing such "indigenous humanitarianism" was illustrated by papers, in this panel and elsewhere, which compared the outcomes for assisted refugees, in settlements or supported programs, with those of self-settled refugees, frequently finding that the later were more successful and more sustainable.

Presentations focusing on the integration experiences of refugees in wealthier countries referred to migrant transna- 
tionalism much more commonly. Concerns about the relationship between transnational practices and integration were expressed in some of the early literature on diasporas, such as work by Safran, who argued that involvement in diaspora networks was more common amongst poorly integrated migrants. ${ }^{6}$ More recently authors such as Portes have challenged this. ${ }^{7}$ The debate between transnational involvement and local integration structured a number of papers. One particular example explored the changing status of Sri Lankan Tamils in Norway, from a position when they were mistrusted, soon after they began arriving as asylum seekers in the 1980s, to more recent developments where they are now seen as a well-integrated and hard-working model minority. The organizations that have supported the successful involvement of Tamils in Norwegian society are also the organizations maintaining strong transnational links with cultural and political developments in Sri Lanka.

In contrast, research on migrants from the former Yugoslavia in Western Europe highlighted the need for refugees to develop "bridging social capital" linking them to society outside of their own ethnic or national social networks. Genuine integration requires a broad network of links across society and it is doubtful that transnational links support, or encourage, the development of such networks. A number of papers, particularly those from practitioners in the field, presented policy interventions that could encourage such interactions. A panel on initiatives to encourage local integration of refugees in the Brazilian context presented a project from São Paulo social services bringing refugees together for a variety of cultural activities. These included an innovative idea of "musical encounters" entitled Cantos de Paz where refugees would come together to sing traditional songs and tell stories as a way of both reinforcing and sharing cultural practices to encourage an appreciation of transnational diversity and simultaneously develop links between different groups.

\section{Transnationalism and Return}

Since the 1990s was declared the decade of repatriation, return has remained the preferred durable solution. Three linked panels focused on Transnationalism and Sustainability in Refugee Return, comprising a total of nine papers exploring the dynamics of post-conflict return to the Balkans, Afghanistan, Iraq, the Democratic Republic of Congo (DRC), and Cambodia. The return of those displaced by war is increasingly viewed as one of the essential constituents of a sustainable peace, yet the difficulties of establishing sustainable return have not been sufficiently explored. "Sustainable return" was identified as more than just a lack of further migration that a simplistic notion of "returning home" may suggest. To be genuinely sustainable, return requires constructive integration and involvement of return migrants which is more difficult to facilitate and difficult to assess. Return is typically considered solely at an individual level but sustainability for communities is more important and may not be the same thing. Sustainability also requires the changes in the nature of that home to be taken into account, even as far as the change of location of home for many refugees displaced by conflict, such those returning to Bosnia. Refugees who fled conflict may face a hostile or suspicious reception on their return from those who did not leave. This was the situation faced by returnees to Afghanistan, Cambodia, and, in some cases, to Bosnia. Returning migrants may provoke envy or resentment in communities at home, particularly if they have achieved some material success whilst in exile. Even so, in some cases the return of exiles may also be welcomed, as research in Iraq and the DRC illustrated.

Transnational strategies may help to overcome the uncertainty of return migration. The resources of the diaspora can be used to support temporary return, so that migrants are not required to make their initial return permanent. Shorter visits can contribute to the reconstruction process and allow returnees to explore the possibility of more permanent re-establishment, gradually, over a period of several visits. Programs such as the UN Development Program's TOKTEN (Transfer Of Knowledge Through Expatriate Nationals) and IOM's MIDA (Migration for Development in Africa) already build on the expertise of transnational communities in this way, encouraging shorter-term returns of skilled expatriates. Patterns of return to Bosnia have operated in this way for some time, with some middle-class expatriates maintaining second homes and returning each year but unwilling to return more permanently due to the lack of suitable employment. In Iraq return is currently a concern of only those migrants who have not prospered in the diaspora; those doing well do not consider return for reasons similar to those of the Bosnian refugees. Research with the Afghan diaspora suggests that individuals are willing to put up with the lower pay and poor conditions of work back in Afghanistan due to the high status of the employment offered to them. This is the principle on which existing schemes to encourage diaspora involvement work.

Discussion in these panels revolved around three significant themes. First, the question was raised of how return affected transnational involvement. Permanent return would clearly end any financial remittances from the migrants in question but there was considerable debate as to whether a refugee who has returned permanently is, in any sense, still transnational. The amount of time an individual 
had spent in exile was considered to be an important factor. A refugee who had been away for some considerable time and continued to interact with individuals who were still living in his or her place of exile may well relate to the world in a substantially different way from those who had never migrated. Even if transnational ties are not utilized, it was argued, they remain important and a transnational perspective would recognize that. As one of the discussants pointed out, a transnational perspective may become so much part of refugees' identity that it remains, even when they are no longer truly transnational. Such a viewpoint uses a transnational perspective to criticize the view that once refugees have returned, once they are back in their "place," everything is back to normal and the natural order has been restored. ${ }^{8}$

A second theme of discussion in these panels was the scale at which transnationalism and return should be evaluated. Although return migration is often considered to be an individual act, sustainable return cannot be considered from an individual perspective, since its success depends on positive engagement with community and national policy structures. A transnational perspective enables the broader significance of these larger-scale structures to be incorporated into the analysis through an individual's social or associational networks. Many of the papers highlighted the role played by associations in the diaspora. Work on Afghanistan highlighted the activities of the Society of Afghan Engineers or the Society of Afghan Professionals at bringing together professionals with the potential to contribute to Afghanistan's reconstruction. In the DRC more regressive racially based cultural organizations such as LORI or ENTE often exacerbated the conflict and provided an example of the dangers of return, or at least the dangers of a precipitated return.

Finally discussion focused on potential policy interventions that could operationalize the positive links between diaspora and sustainable return. Programs of assisted return, frequently administered by governments of wealthier host countries using repatriation grants, were criticized for taking a firmly individualistic perspective on return. The uses of repatriation grants was questioned, and rather than supporting sustainability some research suggested that they only fulfilled basic needs. It was also argued that repatriation grants were typically only claimed by those who had decided to return anyway. One of the major disincentives of such schemes is the requirement to relinquish residence rights in the host country, preventing continued circular migration that may encourage more permanent return. Returnees are unwilling to see return as a one-time, no-going-back event and questions were raised as to how policy could continue to support diaspora solutions to allow a degree of coming and going.
Overall these three panels challenged existing understandings of transnational practices, identifying the more sustainable solutions as those that attempted to involve diaspora networks and extending a transnational perspective to encompass even those individuals who had returned. The problematic nature of "home" is also significant for debates on transnational involvement of refugees whose homes may no longer exist or may be occupied by individuals who did not leave. Other papers on return that were presented at the conference did not make the connection with transnationalism so explicit or consider it so broadly. One particular example focused on post-conflict return in Peru and identified the significance of social capital, in terms of weak bonds in host countries and strong bonds in communities of origin, as one of the most significant determinant influencing why individuals want to return. This is leading towards similar conclusions as these panels, even though the language of transnationalism was not used.

\section{Transnationalism and Resettlement}

Resettlement currently operates for relatively few countries and of these only Australia, Canada, and the US accept resettlement refugees in any significant numbers. Before the conference officially opened a roundtable discussion entitled Access to Durable Solutions? Increasing Protection Capacity in the Regions of Origin was facilitated by members of the Dutch Justice Ministry. They discussed the Communication from the EU Commission that included proposals to significantly extend the limited resettlement programs that currently operate in a few EU member states. ${ }^{9}$ Such developments suggest that resettlement was beginning to be considered more seriously by governments of wealthier countries and similar feelings were voiced by a number of people at the conference. Although, in terms of the number of refugees affected, resettlement is currently the least significant of the three durable solutions, there are indications that its importance may increase.

Resettlement significantly alters the position refugees occupy in their social networks. Even before resettlement, these social networks frequently had a transnational dimension, linking friends and relatives left behind in their home countries with at least one country of first asylum. Several of the papers exploring the resettlement process also identified links between the country of first asylum and resettlement countries that existed before resettlement. From a transnational perspective, therefore, migrants were moving within transnational social fields. ${ }^{10}$ Durable resettlement programs should recognize this and respond to what the change in status within a transnational community means for resettled refugees. Interviews with resettled refugees revealed that much of the information that they were pro- 
vided with before resettlement made little sense to them. Pre-resettlement preparation or induction courses would be advised to recognize and build on the transnational dimension to the resettlement process, incorporating transnational actors into such preparation programs.

A total of seven papers presented in a variety of panels at the conference focused on aspects of the resettlement process of Sudanese refugees. These papers explored resettlement experiences of both Dinka refugees, from Southern Sudan, and of more recent movements from Darfur, and followed them through Cairo to final resettlement countries of the U.S., Canada, and Australia. The practicalities of these movements were, in part, influenced by the fact that they were transnational movements. Since only a small minority of refugees are actually resettled the resettlement process will likely split up refugees' social networks; even those who are resettled may end up in different locations or even on different continents. While some current resettlement programs do have as a goal the maintenance of community, whether it be through the resettlement of an extended family unit or resettlement in locations with which the particular ethnic community already has ties, more research is required to determine whether these goals are, in reality, met and the impact of these goals on successful refugee resettlement. In any case, the resettlement process itself creates and extends transnational networks. Before leaving Cairo one presenter described the send-offs that Sudanese refugees typically receive where they are reminded of the importance of maintaining their traditions and remaining in contact with members of their communities who are not with them.

Such priorities are foremost in the minds of refugees so that when they arrive in the resettlement country they may take care of their transnational obligations before their household or their own needs. One man, resettled to the U.S., spent hundreds of dollars of his initial allowance on phone calls to friends and family around the world and cut back severely on his food budget. The obligations placed on resettled refugees through their transnational relations are frequently a cause of considerable stress. The study of the transnational networks of refugees in the U.S. revealed one individual who was responsible for sending remittances to a total of sixty-three individuals around the world. Notwithstanding data that suggests that resettled refugees are, in the long term, at least as economically successful as the host community, most resettled refugees are not wealthy at the start of the resettlement process and such requirements cannot be fulfilled without considerable self-denial or in some cases cannot be fulfilled at all. Similar results were reported in studies of transnational behaviour in other regions. Refugees from the former Yugoslavia, interviewed in Western Europe, revealed the high proportion of their incomes spent on phone calls, especially in the first phases of their stay there, and the significance of the demands on their resources made by transnational remittance obligations.

\section{Transnationalism and the Search for Solutions}

Beyond the significance of transnationalism in supporting the three traditional "durable" solutions for refugees, work presented at the conference also focused on situations where durable solutions remained elusive. More than six million of the almost ten million refugees in the world in 2003 had been displaced for more than five years, displacement situations described as "protracted" by UNHCR. Some people refer to this situation as the "warehousing" of refugees, and a representative of the U.S. Committee for Refugees and Immigrants presented a review of their anti-warehousing campaign. Strategies to resolve warehousing situations emphasized the need to focus on protection of refugees even in the absence of durable solutions and the significance of recognizing and building on the initiatives of refugees in these situations. Recognizing the transnational element of these initiatives can help identify their significance to the refugees concerned, whereas from a purely local perspective their exact nature may not be obvious.

A number of presentations highlighted the significance of remittances for supporting residents of refugee camps. Although this still casts refugees in camps as passive recipients it does emphasize the significance of refugee-led solutions since it is friends and relatives who have succeeded in establishing themselves elsewhere who are sending the remittances. The potential drawbacks of this situation in terms of the overwhelming obligations placed on refugees were discussed earlier but this is nonetheless a trend which could be supported by development of financial infrastructures in camps to support remittance transfers and reduce the fees that refugees must pay to send money in this way. Evidence was provided not only of the significance of remittances in supporting refugees in camps but also in situations of transit. For example, a paper on urban refugees in Cairo reported estimates that 300 Somali refugees in Cairo receive US\$500,000 a year and 270 Sudanese receive approximately US $\$ 170,000$ a year. This money goes to daily expenditures but also longer-term projects, such as supporting small businesses, and ultimately benefits the local economy in Cairo.

Transnational actions involve more than exchange of money, however significant such exchanges are. A further example of these linkages arose from research in the Dadaab refugee camps for Somali refugees in Kenya. Refugees are usually only acknowledged as actors in protracted 
situations in a negative context, such as images of "refugee warriors," but refugees are also able to engage with political processes more positively. Although refugees in the Dadaab camps were physically separated from their communities of origin their experiences in the camps provided a strong basis for peace-building and conflict-resolution initiatives which could be developed far more. Peace initiatives typically involve representatives of the various armed factions at the time the conflict stops and often do not include others affected by the violence. The situation in the camps, it was argued, provides an ideal opportunity to develop a more sustainable peace. Linked to this point, another study presented at the conference investigated ten different groups of refugees displaced in Kenya. These refugee groups, often numerically very significant and resident in Kenya for many years, are the source of alternative nationalisms in their country of origin. The development of new identities in contexts of prolonged displacement may, in turn, come to affect national identities more broadly.

Several papers reflected this idea of diversity in diaspora, highlighting the heterogeneity of transnational groups. As well as the breadth of origins in terms of language, dialect, ethnicity, social class, and generation, refugees have had very different experiences of exile and displacement. Geographical differences, produced by displacement, have a very strong impact on life chances, education, and access to resources. This diversity across the diaspora can be a resource in solving these protracted situations. A large proportion of foreign aid or humanitarian assistance is the provision of technical expertise and in many cases the potential exists to utilize the expertise of diaspora groups to provide this, as organized programs on temporary return, discussed above are implementing.

\section{Transnationalism and Forced Migration}

The IASFM uses the term "forced migration" to refer to situations of displacement much broader than the definition contained in the 1951 Convention relating to the Status of Refugees. According to the association's Web site, forced migration is "a general term that refers to the movements of refugees and internally displaced people (people displaced by conflicts) as well as people displaced by natural or environmental disasters, chemical or nuclear disasters, famine, or development projects." 11 So far this paper has focused exclusively on refugees, and the nature of transnational relations sustained by refugees. People displaced for other reasons are not likely to differ in their engagement in transnational processes, with two important exceptions.

First, to be transnational the initial movement must cross an international boundary, like refugees themselves. A whole range of papers presented at the conference ex- plored the situation of internally displaced people, including nine papers on the situation of the three million IDPs in Colombia. The attachments between IDPs and their former homes can obviously not be qualified as transnational but perhaps some lessons from the transnational perspective, such as the need to consider contexts of both home and displacement in the search for effective solutions, are also relevant. As research presented on IDPs highlighted, the same range of solutions, limited as they may be for refugees, are not open to IDPs, although for processes of return and local integration, much of what has been noted above may well apply.

A second clear exception is that of development-induced displacement, particularly in the case of dam projects. In these situations there is no home context; not only is there no remaining community of origin, which may also be the case in some refugee situations, but there is no possibility of return. This leads to a re-examination of concepts of return. As suggested in the section of return, it is important to examine the significance of return to the precise location of former residence. Only one paper presented a comparison between refugee movement and development induced displacement, finding the context of displacement very similar between the two groups, but the paper focused on policy interventions and was not concerned with transnationalism.

A final concern, separate from previous considerations, is that of methodology. In exploring the conference theme of searching for solutions several speakers placed an emphasis on the significance of the means of the search. The inclusiveness of the search, it was argued, in terms of involvement of all relevant actors, would contribute to the sustainability of the solutions. For academic research this concern relates to methodological issues and there were three panels focused on methodological concerns. In a setting of transnational movements multi-sited research was common but several papers set out to explore ways of capturing the dynamic of the transnational context in which many refugees found themselves. Techniques included various ways of remaining in contact with individuals from previous research sites, once research had moved on to another site, and innovative uses of the Internet in the research process. ${ }^{12}$

\section{Conclusion}

The significance of discussions of transnationalism in a conference on forced migration marks an important stage in the development of work on migrant transnationalism. Only a few years ago reference to transnational links in work on refugees was rare and tentative. Such widespread use of transnational concepts suggests that they are seen as both 
relevant and useful in work on refugees and that refugees are as actively involved in transnational relations as other migrants. Identifying these links and incorporating them into the research process and policy interventions will lead to a greater understanding of the priorities of refugees and forced migrants. This, in turn, will support a range of solutions which are more appropriate, and recognize more explicitly the efforts that refugees are already undertaking. Such developments both broaden and challenge the transnational perspective. Extending the transnational perspective to less mobile migrants, such as refugees, focuses attention on the significant role played by other forms of exchange in transnational fields such as financial remittances or expertise.

The transnational perspective also contributes to work on refugees. In the context of the conference it emphasizes the role of individual refugees, recognizing their own involvement in the search for solutions: "refugees as solvers." It also highlights the significance of community for refugees: even though that community may be physically separate from them, it can still be the defining influence on their lives. Transnationalism also emphasizes the dominant importance of separation in the construction of meanings, identit,y and family and community relationships and through them influences the relationships refugees create and develop with their societies of residence.

The next conference of the International Association for the Study of Forced Migration will be hosted by the Centre for Refugee Studies at York University, Toronto, in the summer of 2006. A call for papers will be circulated soon. See the IASFM website, <www.iasfm.org $>$ for details.

\section{Notes}

1. N. Al Ali, R. Black, and K. Koser, "Refugees and Transnationalism: The experience of Bosnians and Eritreans in Europe," Journal of Ethnic and Migration Studies, 27, no. 4 (October 2001): 615-34.

2. For an example of the "controversy" of transnationalism, see S. Vertovec, "Trends and Impacts of Migrant Transnationalism" (COMPAS Working paper 04-03, Oxford, 2004).

3. L. E. Guarnizo, A. Portes, and W. Haller, "Assimilation and Transnationalism: Determinants of Transnational Political
Action among Contemporary Migrants," American Journal of Sociology 108, no. 6 (2003): 1211-48.

4. A. Portes, "Transnational Communities: Their Emergence and Significance in the Contemporary World System," in Latin America in the World System, ed. R. P. Korzeniezicz and W. C. Smith (Westport, CT: Praeger, 1996), 163.

5. C. Nagel, "Geopolitics by Another Name: Immigration and the Politics of Assimilation," Political Geography 21 (2002): 971-87.

6. W. Safran, "Diasporas in Modern Societies: Myths of Homeland and Return," Diaspora 1, no. 1 (1991): 83-99.

7. A. Portes, "Introduction: The Debates and Significance of Immigrant Transnationalism," Global Networks 1, no. 3 (2001): 181-93.

8. L. H. Malkki, "Refugees and Exile: From 'Refugee Studies' to the National Order of Things," Annual Review of Anthropology 24 (1995): 495-523.

9. Commission of the European Communities, Communication from the Commission to the Council and the European Parliament: On the managed entry in the EU of person in need of international protection and the enhancement of the protection capacity of the regions of origin ("Improving Access to Durable Solutions”) (Brussels, European Union, COM(2004) 410 final, 4 June 2004).

10. L. G. Basch, N. Glick Schiller, and C. Szanton Blanc, Nations Unbound: Transnational Projects, Postcolonial Predicaments and Deterritorialised Nation States (Amsterdam: Gordon and Breach, 1994.)

11. See the Web site of IASFM at $<$ http://www.iasfm.org $>$.

12. See, for example, the article by Cindy Horst in the present issue.

Michael Collyer is a research fellow in the Department of Geography and the Sussex Centre for Migration Research at the University of Sussex, Brighton, UK. He was general rapporteur for IASFM 9 and, with Ronald Kalyango of Makerere University in Uganda, chairs the program committee for IASFM 10, to be held in Toronto in the summer of 2006. His own research is focused on links between North African migrant communities living in Europe and their regions of origin. For the past year he has been based at Abdelmalek Essaadi University in Tétouan, Morocco. 